\title{
A védett munkahelyek jogi és pszichológiai hatása a megváltozott munkaképességúek foglalkoztatásában, egy érintett szemszögéből
}

\author{
The juristic and psychologic effect of the protected workplaces \\ in the employment of disadventaged workers, from the aspect \\ of an involved author
}

\author{
Szerzők: Lengyel Júlia $\bowtie$ \\ Család- és Gyermekjóléti Központ
}

Beküldve: 2018. 06. 11.

doi: 10.24365/ef.v59i5.321

\begin{abstract}
Összefoglaló: Ahhoz, hogy a fogyatékkal élők a társadalom egyenrangú, elfogadott tagjai lehessenek, elengedhetetlen részvételük a munka világában. Hazánkban jogi szabályozással törekszenek rá, hogy biztosítsák az érintett célcsoport munkába állítását. Ez a fejlődési utat nyújtó fejlesztő foglalkoztatás, az akkreditált foglalkoztatás és az integrált, nyílt munkaerőpiaci foglalkoztatás formáiban történik. Ugyanakkor megállapítható, hogy a jelenleg többségben lévő társadalmi gondolkodás, a sztereotípiák nem teszik lehetővé a kidolgozott jogszabályi háttér maradéktalan alkalmazását. A jogi szabályozás teljes körü betartásához elengedhetetlen a radikális szemléletváltás. Kulcsszavak: fogyatékkal élők; védett foglalkoztatás; esélyegyenlőség
\end{abstract}

\begin{abstract}
Summary: It is essential for people with disabilities to take part in the world of work if they are to become equal, accepted members of society. Our country is striving to ensure the employment of the target group concerned with its legislation, in the forms of developmental employment providing a certain way to improvement, accredited employment and integrated open labour market employment. At the same time, it can be stated that the social thinking and the stereotypes that are predominant at present do not enable the elaborated legislative background to be fully enforced. I consider a radical change of approach to be indispensable for the complete observance of the legal regulation.
\end{abstract}

Keywords: people with disabilities; sheltered employment; equal opportunities

\section{BEVEZETÉS}

Amikor a fogyatékkal élókkel, megváltozott munkaképességúekkel foglalkozom, mindenekelőtt fontosnak vélem a célcsoporthoz tartozók definiálását. Kutatók szakmai vitáinak sorozataként számtalan tudományos fogalom alakult ki, ennek ellenére álláspontom az, hogy az érintettek társadalmi megítélésének lényegét, az őket körüllengő problémák összefoglaló magyarázatát azon jogalkotói leírás adja, amely szerint „,a fogyatékos emberek a társadalom egyenlő méltóságú, egyenrangú tagjai, akik a mindenkit megillető jogokkal és lehetőségekkel csak jelentős nehézségek árán vagy egyáltalán nem képesek élni.." ${ }^{1}$ Mindezek alapján hazánkban, mint a közel egymillió före tehető rokkantosított személy országában, szükségesnek tartanám a radikális szemléletváltást a megváltozott munkaképességűek foglalkoztatása területén, többek között a törvényileg megengedett pozitív diszkrimináció eszközének hatékonyabb alkalmazásával. Elmondható, hogy az elmúlt évtizedekben a fogyatékosságpolitika, illetve a fogyatékos mozgalom a befogadás elveit kitűzve igyekezett előmozdítani az érintett emberek mind szélesebb körű társadalmi részvételét. Emellett a fogyatékos, valamint megváltozott munkaképességú emberek munkaerőpiaci helyzete, aktivitása egyre 
gyakrabban került a fejlett országok érdeklődésének középpontjába, valamint a nemzetközi szervezetek számos dokumentumban javasolták az országok számára az alig néhány százalékban foglalkoztatott, megváltozott munkaképességú személyek munkaerőpiacra történő bevonásának szélesítését, részképességeik hasznosítását, a passzív szerep helyett a meglévő képességek mentén a munka világába integrált társadalmi szerep kialakítását. Számtalan államban a betegséget olyan átmeneti problémának tekintik, amelynek megoldását követően az érintett személy visszatér némi változással terhelt, ám normális életviteléhez. Ebből kifolyólag a társadalmi megítélés a betegséget nem tartja jellemhibának, továbbá nem hagyja, hogy a fogyatékossággal élő sajnáltassa, csökkent értékűnek tekintse magát, valamint beletörődjön küzdelmekkel teli helyzetébe. Meglátásom szerint az egészséges mentalitásnak önmagában is gyógyító ereje van, így kiemelten fontosnak tartom ennek kialakítását, erősítését a megváltozott munkaképességű személyekben ahhoz, hogy teljes értékűként élhessék életüket. Jelen írásomban ezen mentalitásfejlődési folyamat keretében vizsgálom a munkavégzés mint alkalmazott terápia hatását.

Látássérült munkavállalóként a jogi háttér szükségszerủ bemutatása mellett a személyes, valamint az érintett célcsoport gyakorlati tapasztalásait veszem górcső alá. A felhasznált irodalom választása során vezérelvem elsősorban a téma aktualitásának hangsúlyozása volt. Ebből kiindulva igyekeztem összegyújteni és legteljesebben bemutatni a hatályos jogszabályokat, valamint meglátásom szerint a foglalkozási rehabilitáció területén különösen jelentős munkát végző civil szervezet, a Fogyatékos Személyek Esélyegyenlőségéért Közhasznú Nonprofit Kft. kutatási eredményeit. E viszonylag szúkre szabott irodalmi keret teljességét törekszem biztosítani személyes tapasztalásaim, gondolataim, elképzeléseim megfogalmazásával.

\section{JOGSZABÁLYI ALAPVETÉS}

A változtatás lehetőségének táptalaját adja a jelenleg hatályban lévő Alaptörvényünk, amikor megfogalmazza, hogy a „közösség erejének és minden ember becsületének alapja a munka, az emberi szellem teljesítménye.” "Magyarország törekszik megteremteni annak feltételeit, hogy minden munkaképes ember, aki dolgozni akar, dolgozhasson." ${ }^{2}$ Ezzel összhangban hazánk jogszabályi szinten igyekszik biztosítani a fogyatékkal élók lehetőség szerint integrált, ennek hiányában védett foglalkoztatását. A foglalkozási rehabilitáció hazai rendszere az elmúlt évtizedekben jelentős átalakuláson ment keresztül, amely érintette nemcsak a szabályzók, hanem a szemlélet, minősítés, az ellátási formák, a támogatási rendszerek és az intézményi rendszer változását is. A komplex rehabilitáció szemléletének megjelenése és gyakorlati alkalmazása új elvárásokat hozott mind az állami feladatellátás, mind pedig az államon kívüli civil és gazdasági szereplők vonatkozásában.

\section{FOGLALKOZÁSI REHABILITÁCIÓ}

\section{A foglalkozási rehabilitáció jellemzői, a nyílt munkaerőpiaci foglalkoztatás mint elérendő cél}

A komplex rehabilitációs folyamat alapvetően több területből áll, így a foglalkozási rehabilitáció csupán egy részterület az orvosi, a mentálhigiénés, a szociális, valamint a pedagógiai rehabilitáció mellett. A foglalkozási rehabilitáció elsősorban a munkaerőpiacra történő visszalépés elősegítésére irányul. A foglalkozási rehabilitáció folyamatának és eszközrendszerének tervezése személyre szabott, aminek kiinduló feltétele az egyén fejleszthető képességeire épülő munkavállalási stratégia, amely elsősorban az egészségkárosodás mértékéhez, a megmaradt képességekhez és a munkaerőpiaci esélyekhez igazodik. ${ }^{3}$

Elmondható, hogy a megváltozott munkaképességűek foglalkoztatásának előmozdításában jelentős szerepet játszanak az államon kívüli, civil vagy gazdasági szereplők. Bár az állami és államon kívüli szolgáltatók munkájának célja azonos, más eszközökkel és támogatásokkal érik el mindezt. Az államon kívüli szolgáltatók az egyén megismerésén, felmérésén, egyénre szabott felkészítésén keresztül találják meg a megváltozott munkaképességú ember számára az ideális foglalkoztatási formát, munkakört, illetve segítik nemcsak a beilleszkedést, hanem az utókövetéssel a tartós foglalkoztatás elérését is. Az állami szolgáltatók a munkaadóknak biztosított ösztönzők segítségével érik el a fogyatékos, illetve egészségkárosodott emberek elhelyezését. Az állami intézmények munkája mellett közel 
húsz éve kezdték meg tevékenységüket az első alternatív munkaerőpiaci szolgáltatást nyújtó civil szervezetek. A megváltozott munkaképességú emberek különböző hátrányaira speciális, komplex megoldásokkal reagáltak. Céljuk a fogyatékos emberek nyílt munkaerőpiaci munkavállalásának támogatása. Az álláskeresők számára, több éves szolgáltatási tapasztalataikra építetten, személyre szabott, rugalmas szolgáltatás biztosítja a civil szervezetek programjának sikerességét és hatékonyságát. Széles körű munkáltatói kapcsolatrendszer okán a nyújtott szolgáltatás a befogadást, bennmaradást és a szemléletformálást segíti elő. Emellett a foglalkozási rehabilitáció kiszélesítésével és a munkáltatói támogatások megjelenésével párhuzamosan nagymértékben nőtt az igény megváltozott munkaképességú emberek felvételére. Számos, munkaközvetítéssel, illetve munkaerő-kölcsönzéssel foglalkozó cég kezdte kibővíteni a közvetítési palettáját e célcsoportra. ${ }^{3}$ A mindezen szolgáltatók által célul kitűzött nyílt piaci munkavállalás az egészségkárosodott emberek foglalkoztatásának legmagasabb szintje. Az integráció és a társadalmi befogadás itt valósul meg legteljesebben. E foglalkoztatási keretben a fogyatékkal élő emberek végzettségüknek, képességeiknek, motivációiknak, személyes erősségeiknek, valamint egészségi állapotuknak megfelelő munkahelyen és elfogadó környezetben egészséges embertársaik között dolgozhatnak. Ugyanakkor látnunk kell azt is, hogy magas azoknak az egészségkárosodott személyeknek a száma, akiknek a nyílt piaci foglalkoztatását nem teszi lehetővé akár pillanatnyi, akár végleges állapota. Ahogy azt alább is kifejtem, vallom, hogy az e körbe tartozók teljes körű, sikeres rehabilitálásához kikerülhetetlen a munkavégzés mint terápiás eszköz. Ha röviden áttekintjük a védett foglalkoztatási formák, így az akkreditált foglalkoztatás és a fejlesztő foglalkoztatás területét, láthatjuk, hogy egyfajta fejlődési utat jelentenek a nyílt piaci foglalkoztatás felé az egészségében bármely okból megkárosodott, és azt csapásként megélő, pszichésen tönkrement, ámde újra felállni akaró, küzdeni képes emberek számára.

\section{Fejlesztő foglalkoztatás}

2017 januárjában megszületett és elfogadásra került az a jogszabály, amely az eddigi intézményen belüli szociális foglalkoztatást megszüntette, és helyébe 2017. április 1-től bevezette a fejlesztő foglalkoztatást. A kialakításra került fejlesztő foglalkoztatás célja, hogy a gondozási, fejlesztési, illetve rehabilitációs tervben foglaltak szerint az egyén egészségi állapotának, életkorának, fizikai és mentális állapotának megfelelően fejlesztési és foglalkoztatási szolgáltatást nyújtson, ezáltal támogatva az egyén önálló munkavégzésre, illetve a nyílt munkaerőpiaci elhelyezkedésre való felkészítését. ${ }^{4}$ Mindez a gyakorlatban azáltal valósulhat meg, ha a fejlesztő foglalkoztatás lehetőséget biztosít az értékteremtő foglalkoztatás létrehozására, tehát nem a képességbeli hiányosságokra, hanem a megmaradt képességekre fekteti a hangsúlyt. A fejlesztő foglalkoztatás az integráció támogatásával biztosítja a fogyatékos emberek munkaerőpiachoz való hozzáférését és törekszik arra, hogy a munkaképes lakók minél nagyobb létszámban jussanak munkához, továbbá a munkán keresztül esélyt kapjanak a helyi közösségekbe való beilleszkedésre. E foglalkoztatási forma a rehabilitációs célhoz kapcsolódóan elvárja, hogy a foglalkoztatás módja és a megjelenő elvárások, szabályok és feltételek minél inkább közelítsenek a nyílt munkaerőpiaci kritériumok jellemzőihez. Mindezt támogathatja a piacorientált szemléletmód erősítése, amely egyben a fenntarthatóság, a fejlesztés kulcsát is jelenti. ${ }^{5}$ A fejlesztő foglalkoztatás kétfajta jogviszonyt különböztet meg: a szociális törvény szerinti fejlesztési jogviszonyt és a Munka Törvénykönyve szerinti határozott idejú munkaviszonyt, ami lehetővé teszi a képesség alapú differenciálást, és átlépési lehetőséget kínál az akkreditált vagy nyílt munkaerőpiaci munkavállalás felé. ${ }^{4}$ Alanya olyan fogyatékossággal élő pszichiátriai beteg, szenvedélybeteg vagy hajléktalan személy lehet, aki szociális szolgáltatásban' vagy ellátásbanii részesül. A fejlesztési jogviszonyban történő foglalkoztatás célja az ellátott testi és szellemi képességeinek,

\footnotetext{
i Az 1993. évi III. törvény szerint szociális szolgáltatásnak minősül a közösségi alapellátás, támogató szolgáltatás, nappali ellátás, átmeneti elhelyezést nyújtó intézményi ellátás, ápolást-gondozást nyújtó intézményi ellátás, rehabilitációs intézményi ellátás, lakóotthoni ellátás és a támogatott lakhatás.

"Az 1993. évi III. törvény alapján a szociális ellátások két nagy csoportra oszthatók: pénzbeli és természetbeni ellátásokra. Pénzbeli ellátásnak minősül az időskorúak járadéka, az aktívkorúak ellátása, az ápolási díj, valamint a települési támogatás. Természetbeni ellátásnak minősül a közgyógyellátás, az egészségügyi szolgáltatásra való jogosultság és a köztemetés.
} 
valamint a munkavégzéssel összefüggő készségeinek helyreállítása, megőrzése és fejlesztése, továbbá az ellátott felkészítése az önálló munkavégzésre.

A fejlesztési jogviszony a pszichológus szakember javaslata, vagy rehabilitációs alkalmassági vizsgálat eredményeképpen kiadott, hatályos, munkarehabilitációt javasoló szakvélemény alapján, egyéni foglalkoztatási tervben foglaltak szerint akkor hozható létre, ha az ellátott kompetenciái nem érik el az önálló munkavégzéshez szükséges szintet. ${ }^{4}$

\section{Akkreditált foglalkoztatás}

Az akkreditált foglalkoztatás fontos állomás lehet a megváltozott munkaképességú személyek foglalkozási rehabilitációja során. Előrelépést jelent a fejlesztő foglalkoztatás irányából, fokozatos átmenetet és felkészítést biztosít a nyílt munkaerőpiac felé, ezáltal magasabb szinten garantálja a foglalkoztatást, szélesíti az egyéni képességekhez igazított rehabilitáció eszköztárát. Amíg a fejlesztő foglalkoztatásnál elsősorban a munkakészség fejlesztésén, munkatípusok kipróbálásán, munkaszocializáción van a hangsúly, az akkreditált foglalkoztatás ezen már túlmutat. A megmaradt készségek hasznosítását és fejlesztését túzi ki célul a nyílt munkaerőpiaci érvényesülés érdekében. Az akkreditált foglalkoztatás, mint a foglalkozási rehabilitáció színtere, több funkcióval rendelkezik. Egyrészt előrelépést jelent a fejlesztő foglalkoztatás irányából, megfelelő feltételeket teremt az integrált foglalkoztatásba még bekapcsolódni nem tudó, megváltozott munkaképességű emberek számára amellett, hogy védett környezetet biztosít az ott dolgozóknak. Elvárásokban már közelít a nyílt munkaerőpiaci feltételekhez, segítő szolgáltatások által támogatja a foglalkozási rehabilitáció megvalósulását, a felkészülést a nyílt munkaerőpiaci munkavállalásra. ${ }^{6}$

Az akkreditációs cél szempontjából beszélhetünk tartós és tranzitfoglalkoztatásról. A tartós foglalkoztatás célja a megváltozott munkaképességű munkavállaló munkakészségének, egészségi állapotának, testi és szellemi képességeinek megőrzése, fejlesztése, termelő, szolgáltató tevékenység biztosítása mellett, védett körülmények között, munkaviszony keretében. A tranzitfoglalkoztatás célja pedig a rehabilitálható munkavállaló felkészítése a nyílt munkaerőpiacon történő foglalkoztatásra, védett körülmények között, termelő, szolgáltató tevékenység biztosítása mellett. ${ }^{7}$ Ha megvizsgáljuk a két foglalkoztatási formát, megállapítható, hogy az akkreditált foglalkoztatónál történő munkavállalás elsődleges célja a megváltozott munkaképességű személyek meglévő munkavégző képességeinek feltárása, megőrzése és fejlesztése, munkatapasztalat és gyakorlat biztosítása.

Akkreditált foglalkoztatásban olyan megváltozott munkaképességű személyek vehetnek részt, akik rendelkeznek a fentiekben már említett komplex minősítéssel.iii Azoknak a cégeknek pedig, melyek vállalják a rehabilitációs foglalkoztatást, akkreditációs eljárásban kell részt venniük, amelynek végén a jogszabályban leírt feltételek teljesülése esetén rehabilitációs akkreditációs tanúsítványt kapnak. A tanúsítványt határozatlan időre állítják ki, de évenként ellenőrzik, hogy a vállalatok továbbra is megfelelnek-e az akkreditációs követelményeknek.

\section{A FOGYATÉKOSSÁG PSZICHOLÓGIAI OLDALA SZEMÉLYES TAPASZTALÁSAIM FÉNYÉBEN}

\begin{abstract}
A fogyatékosság pszichológiai velejáróiról számos elismert szakember tudományos eredményeit lehetne felsorakoztatni, pró és kontra összevetni, de hosszas gondolkodás után másra jutottam: mivel meglehetősen kevés az a fórum, ahol a fogyatékkal élő ember hozzáértő szakmabeliek előtt nyilatkoztatja ki az általa megélteket, így mint fogyatékkal élő szerző, talán mint a sok közül az egyik leghitelesebb forrás írom le tapasztalásaimat a foglalkoztatás területén. Leszögezem, hogy kizárólag a látássérültek nevében fejtem ki álláspontomat, hisz minden fogyatékos csoport más speciális problémával küzd. Mindenekelőtt különbséget kell tennem a született vakok és a gyermek- vagy felnőttkorban szerzett vaksággal élők között. A született vakoknak a teljes sötétség világa a természetes, ebben nevelkednek, szocializálódnak, így a mindennapi nehézségekből fakadó lelki gyötrelmeken túl nem élik meg az egészséges állapot elvesztésének gyászfolyamatát.
\end{abstract}

\footnotetext{
iii Jogszabályi követelmény, hogy a rehabilitációs hatóság komplex minősítése alapján B1, C1, B2, C2, D, E besorolásba tartozzon a megváltozott munkaképességü személy.
} 
Esetemben kamaszkoromban derült ki, hogy látóideg-sorvadásban szenvedek, amelynek végkifejlete a teljes vakság. Lélektanilag rendkívül hosszú folyamat vezetett a beletörődés fázisáig. Kár is lenne hazudni, a betegséggel együtt élni lehet és kell, szükséges az egészséges, építő betegségtudat kialakítása, de azt teljes mértékben elfogadni nem lehetséges. Az első időben a tagadás fázisát éltem. Rendkívüli szégyenérzet gyötört látásromlásom miatt. Nehezemre esett közösségbe menni, és felvállalni azt, hogy mások segítségére szorulok. A vakok életét jelentősen megkönnyítő segédeszközöket teljesen elutasítottam. Hamar rá kellett jönnöm, aligha várhatom, hogy mások elfogadjanak, segítsenek, ha önmagam elfogadására sem vagyok képes. Itt kell hangsúlyozni azt, hogy nagyon sok látássérült a folyamat ezen szakaszában megreked, élete az önsajnálatra, depresszióra korlátozódik. Az ebben a helyzetben élőknek szükségük van külső segítségre, hogy a gyógyulás, a foglalkozási rehabilitáció útján elindulhassanak. Sokat lendít önmagunk elfogadtatásában a támogató környezet, család, barátok.

Ha a munka világát vizsgálom, nem lehet szépíteni, hogy a hazai látássérültek alulfoglalkoztatottak. Végzett jogászként is rendkívül nehezen találtam meg a helyem a nyílt munkaerőpiacon. Az állásinterjúk tengere nem hogy eredményre nem vezetett, de emellett hatalmas lelki sérülést is okozott. A munkáltatók mondva csinált indokaikkal elutasítottak, aminek következtében egyre nőtt bennem az érzet, hogy semmire sem vagyok jó. Óriási erő kell ahhoz, hogy a csapások sora ellenére fel tudjak állni, és tovább keressem helyemet a munka világában. Úgy gondolom, hogy az önmagunk elfogadtatását követően ez az a pont, amikor a fogyatékkal élőnek külső segítségre lehet szüksége a kitartás erősítésében, az önbecsülés megtartásában.

A foglalkoztatás területét nézve pályafutásom pozitív. Megtaláltam helyem egy szociálisan rendkívül érzékeny vezető közremúködésével a Család- és Gyermekjóléti Központban. A szociális szféra megtanította átértékelni az életem. A munkám során tapasztalt sanyarú sorsok láttán megbecsülöm önmagam, könnyebben viselem a fogyatékosságból fakadó mindennapi nehézségeket, valamint erőt ad az, hogy tudásommal segíthetek a rászoruló embereken.

\section{ÖSSZEFOGLALÁS}

Áláspontom szerint a fogyatékkal élők teljes értékű életviteléhez, önbecsüléséhez elengedhetetlen a kiszámítható, rendszerszerú napirend, a munka útján a társadalomhoz tartozás érzete. Felmérések is alátámasztják, hogy a munkának terápiás hatása lehet. Azoknak a fogyatékkal élóknek, akik munkát végeznek, életminőségük jelentős mértékben javul a passzív, sorsuk beteljesülését otthonukban tétlenül váró sorstársaikhoz képest. Kiegyensúlyozottabbak, boldogabbak. Nagyobb az önbecsülésük, szilárdabb a lelki egyensúlyuk, optimistább a világképük.

Személyes tapasztalásom is az, hogy a munkavégzés útján teljesedik ki egy fogyatékkal élő ember élete. Munkavégzés közben megjelenik a társadalmi hasznosság, egyenlőség érzete. Mindezt alátámasztják egy szintén látássérült sorstársam gondolatai is: „A munka nekem a túlélésben segít. Teljes értékú életet szeretnék élni, mint amikor láttam, és ebbe beletartozik a munkavégzés is! Szociális munkásként, mentálhigiénésként dolgozom, hogy én segíthessek a nálam nehezebb helyzetben lévőknek." Ugyanakkor azt is le kell szögeznünk, hogy hiába a tökéletesen kialakított jogszabályi háttér, ha annak alkalmazása főként a társadalmi szemléletnek köszönhetően akadályokba ütközik. Sok esetben nem találkozik a munkaerőpiaci kereslet és kínálat arra tekintettel, hogy a munkáltatók a kialakult sztereotípiák miatt félnek alkalmazni egy egészségében károsodott személyt. Nincsenek tisztában a munkavégzés feltételeivel, a speciális igényekkel, körülményekkel, ennélfogva a fogyatékkal élő esélyt sem kap arra, hogy egyáltalán az állásinterjúig eljusson, és a munkáltató felmérhesse kompetenciáit. Azok a munkáltatók, akik alkalmaznak megváltozott munkaképességű munkavállalót, hosszabb távú tapasztalattal rendelkeznek a fogyatékkal élők teherbíró képességéről és munkához való hozzáállásáról, beszámoltak arról, hogy az érintett munkavállalók sokkal többet teljesítenek, jobban megbecsülik a munkát azért, hogy bebizonyíthassák értékeiket, valamint a munkára való rátermettségüket.

A foglalkozási rehabilitáció hatékonyabb múködésében, mind szélesebb körű alkalmazásában meghatározó szerepet tölthetnek be az egészségügyi dolgozók, pszichológusok. Tapasztalatom az, 
hogy a felnőtt korban valamilyen fogyatékosságot szerzett, vagy a születéskor öröklött, de folyamatosan romló állapotú emberek önbecsülésüket vesztettekké válnak. A fogyatékosság korai stádiumában a legfontosabb feladat az egészséges, a mindennapokat előremozdító betegségtudat kialakítása, ami talán egy fogyatékos embernek a legnehezebb. Könnyen kerülünk az önsajnálat, depresszió stádiumába, ami nem teszi lehetővé a munkaterápia gyógyító hatásának kibontakoztatását. Talán az egészségügyi dolgozók szakértelmükkel, önfejlesztő tréningekkel, csoportos beszélgetésekkel, terápiák szervezésével mutathatják az utat a fogyatékos ember számára az elfogadás útvesztőjé- ben. Mindenképp hangsúlyozni szeretném, hogy az illetékes személyek nyújtsanak kezdeményező kezet a négy fal közé beszorult, lelki megerősitésre vágyó fogyatékkal élőnek, ne várják, míg bekopogtat a segítségért, mert a segélyhívás a lakások falai közé szorul.

Köszönetet mondok mindazon olvasóknak, akik a jelen közlemény elolvasását követően közremúködnek a megváltozott munkaképességú, egészségkárosodott személyek minél szélesebb körű foglalkoztatásának elősegítésében. Márai Sándort idézve tudom legjobban kifejezni a társadalom szemléletváltásáért vívott küzdelem célját: „Tegyünk meg mindent értük, de semmit se helyettük!"

\section{HIVATKOZÁSOK}

\footnotetext{
${ }^{1}$ A fogyatékos személyek jogairól és esélyegyenlőségük biztosításáról szóló 1998. évi XXVI. törvény

2 Magyarország Alaptörvénye

${ }^{3}$ Fogyatékos Személyek Esélyegyenlőségéért Közhasznú Nonprofit Kft. A foglalkozási rehabilitáció intézményrendszere. http://fszk.hu/kiadvany/a-foglalkozasi-rehabilitacio-intezmenyrendszere/ Elérve: 2018. 09. 06.

${ }^{4}$ 1993. évi III. törvény a szociális igazgatásról és a szociális ellátásokról

${ }^{5}$ Fogyatékos Személyek Esélyegyenlőségéért Közhasznú Nonprofit Kft. Fejlesztő Foglalkoztatás. http://fszk.hu/kiadvany/fejleszto-foglalkoztatas/ Elérve: 2018. 09. 06.

${ }^{6}$ Fogyatékos Személyek Esélyegyenlőségéért Közhasznú Nonprofit Kft. Akkreditált Foglalkoztatás. http://fszk.hu/kiadvany/akkreditalt-foglalkoztatas/ Elérve: 2018. 09. 06.

7 327/2012 (XI. 16.) kormányrendelet a megváltozott munkaképességű munkavállalókat foglalkoztató munkáltatók akkreditációjáról, valamint a megváltozott munkaképességű munkavállalók foglalkoztatásához nyújtható költségvetési támogatásokról. https://net.jogtar.hu/jogszabaly?docid=a1200327.kor Elérve: 2018. 09. 06.
} 